\title{
Carbonarones A and B, New Bioactive $\gamma$-Pyrone and $\alpha$-Pyridone Derivatives from the Marine-derived Fungus Aspergillus carbonarius
}

\author{
Yapeng Zhang, Tianjiao Zhu, Yuchun Fang, Hongbing Liu, Qianqun Gu, Weiming Zhu
}

Received: September 26, 2006 / Accepted: February 7, 2007

(C) Japan Antibiotics Research Association

\begin{abstract}
Two new secondary metabolites, carbonarones A (1) and B (2), were obtained from the culture of the marine-derived fungus Aspergillus carbonarius isolated from the marine sediment collected at Weizhou island of China. Based on ESIMS, 1D and 2D NMR data, and the X-ray crystallographic analysis, their structures were elucidated as 6-benzyl-4-oxo-4H-pyran-3-carboxamide and 6-benzyl-4-hydroxy-2-oxo-1, 2-dihydropyridine-3carbaldehyde, respectively. $\mathbf{1}$ and $\mathbf{2}$ showed moderate cytotoxicity against $\mathrm{K} 562$ cells with $\mathrm{IC}_{50}$ values of 56.0 and $27.8 \mu \mathrm{g} / \mathrm{ml}$, respectively.
\end{abstract}

Keywords Aspergillus carbonarius, carbonarones, marine-derived microorganisms, cytotoxicity

\section{Introduction}

Marine microorganism is a rich source of secondary metabolites with diverse structures and various biological activities, such as cytotoxic [1], antitumor [2], antimicrobial [3], and antimycobacterial [4] activities. In our continuing research on antitumor secondary metabolites from marine-derived microorganisms, a culture extract of an Aspergillus carbonarius strain isolated from the marine sediment collected at Weizhou Island, China, showed significant cytotoxic activity against K562 cell line at $10.0 \mu \mathrm{g} / \mathrm{ml}$. It was reported that the secondary

Q. Gu, W. Zhu (Corresponding author), Y. Zhang, T. Zhu, Y. Fang, H. Liu: Key Laboratory of Marine Drugs, Ministry of Education, Institute of Marine Drugs and Food, Ocean University of China, Qingdao 266003, PR China E-mail: weimingzhu@ouc.edu.cn, guqiang@ouc.edu.cn metabolites of A. carbonarius include ochratoxin A [5], citric acid, fonsecin [6] and the carbonarins $A \sim \mathrm{H}$ [7]. The latter were effectively used to control Coleopteran and Lepidopteran insects. Further chemical investigation on metabolites of this fungal species was carried out, which led to the isolation and structural elucidation of two new compounds, carbonarones A (1) and B (2), (Fig. 1) via bioassay-guided isolation procedure.

The bioactive secondary metabolites of the $A$. carbonarius were obtained from the EtOAc extract of the fermentation broth and mycelia. Isolation of the compounds was achieved by repeated chromatographic steps, including column chromatography on silica gel, Sephadex LH-20 and reversed-phase semipreparative HPLC.

\section{Materials and Methods}

Strain

The fungus strain Aspergillus carbonarius WZ-4-11 was isolated from the marine sediments collected in Nov. 2003 at Weizhou Island, Guangxi Province, China and identified according to its morphological characteristic by Prof. Li Tian (First Institute of Oceanography, State Oceanic<smiles>NC(=O)c1coc(Cc2ccccc2)cc1=O</smiles><smiles>O=Cc1c(O)cc(Cc2ccccc2)[nH]c1=O</smiles>

Fig. 1 Structures of carbonarones A (1) and B (2). 
Administration, Qingdao, China). Working stocks were prepared on Potato Dextrose agar slants stored at $4^{\circ} \mathrm{C}$.

\section{Fermentation}

The strain A. carbonarius WZ-4-11 was grown under static conditions at $24^{\circ} \mathrm{C}$ for 30 days in one hundred and fifty $1000-\mathrm{ml}$ conical flasks containing the liquid medium (300 ml/flask) composed of (g/liter): glucose (20.0), peptone (5.0), malt extract (3.0) and yeast extract (3.0) and sea-water (pH adjusted to 7.0).

\section{Extraction and Isolation}

The culture broth (45 liters) was filtered through cheese cloth to separate the mycelia. The filtrate (40 liters) was concentrated under reduced pressure to about a quarter of the original volume and then extracted with ethyl acetate $(3 \times 13$ liters $)$. The wet mycelium was extracted with acetone $(3 \times 3$ liters $)$ which was later removed under reduced pressure. The resulting aqueous solution was extracted with ethyl acetate $(3 \times 3$ liters). All ethyl acetate solutions were combined and evaporated to dryness under reduced pressure to give a crude extract $(124.1 \mathrm{~g})$.

The crude extract (124.1 g) was separated into 15 fractions by column chromatography on silica gel (200 300 mesh, column size $90 \times 400 \mathrm{~mm}$, content of silica $230.0 \mathrm{~g})$ using a step gradient elution (chloroform/methanol). The active fraction $2(403 \mathrm{mg}$ ) was crystallized from methanol yielding $20 \mathrm{mg}$ of $\mathbf{2}$ as colorless needles. The mother liquor was subjected to column chromatography on Sephadex LH-20 with $\mathrm{CHCl}_{3}-\mathrm{MeOH}$ $(50: 50)$ as eluting agent and was separated into 3 subfractions. Subfraction $2 \sim 3 \quad(52 \mathrm{mg})$ was further separated by semipreparative HPLC using an ODS column (Capcell Park $\mathrm{C}_{18}$, column size $10 \times 250 \mathrm{~mm}$, particle size $5 \mu \mathrm{m}$, flow rate $4 \mathrm{~mL} /$ minute) with $65 \% \mathrm{MeOH}-\mathrm{H}_{2} \mathrm{O}$. Fractions containing 1 were combined according to the UV characteristics and the retention time and then evaporated to dryness to obtain the pure compound $\mathbf{1}(6.0 \mathrm{mg})$.

\section{Biological Assay}

Inhibition of the human leukemia cell lines K562 proliferation and cytotoxicity were measured by the sulphorhodamine B (SRB) assay [8]. Cells were plated in 96-well plates and allowed to attach and grow for 24 hours. The compounds or vehicle $(\mathrm{MeOH})$ was added and incubated with the cells for 48 hours. Following drug exposure, the cells were fixed with $10 \%$ trichloroacetic acid at $4^{\circ} \mathrm{C}$ for 1 hour, and then the cell layer was stained with an SRB solution $(0.4 \%)$ for 30 minutes. Excess stain was washed off with $1 \% \mathrm{AcOH}$, and the SRB was solubilized with $10 \mathrm{mM}$ Tris base for 1 hour on an orbital shaker. The absorbance of the SRB solution was measured at $520 \mathrm{~nm}$. Dose-response curves were generated, and the $\mathrm{IC}_{50}$ values calculated from the linear portion of the log dose-response curves.

\section{Results and Discussion}

\section{Physico-chemical Properties}

Carbonarone A (1): yellow amorphous powder; HRESIMS $m / z 230.0819[\mathrm{M}+\mathrm{H}]^{+}$(calcd for $\mathrm{C}_{13} \mathrm{H}_{12} \mathrm{NO}_{3}, 230.0817$ ). UV (MeOH) $\lambda_{\text {max }}(\log \varepsilon) \mathrm{nm} 279$ (4.20), 317 (3.66), 401 (3.60); IR $v_{\max } \mathrm{cm}^{-1}(\mathrm{KBr}) 3350,2952,2355,1759,1679$, 1610, 1567, 1414, 1243, 1162, 1070, 937, 718, 697. ${ }^{1} \mathrm{H}$ $\left(\mathrm{CDCl}_{3}, 600 \mathrm{MHz}\right)$ and ${ }^{13} \mathrm{C}\left(\mathrm{CDCl}_{3}, 150 \mathrm{MHz}\right)$ see Table 1.

Carbonarone B (2): colorless needle; $\mathrm{mp} 209 \sim 209.5^{\circ} \mathrm{C}$; HRESIMS $m / z 230.0824[\mathrm{M}+\mathrm{H}]^{+}\left(\right.$calcd for $\mathrm{C}_{13} \mathrm{H}_{12} \mathrm{NO}_{3}$, 230.0817). UV (MeOH) nm $\lambda_{\max }(\log \varepsilon) 340$ (3.87); IR $v_{\max } \mathrm{cm}^{-1}(\mathrm{KBr}) 3032,2912,2826,2754,1673,1613$, $1560,1295,1253,824,755,692,519 .{ }^{1} \mathrm{H}\left(\mathrm{CDCl}_{3}\right.$, $600 \mathrm{MHz})$ and ${ }^{13} \mathrm{C}\left(\mathrm{CDCl}_{3}, 150 \mathrm{MHz}\right)$ see Table 1.

\section{Structure Determination}

Carbonarone A (1) was obtained as a yellow amorphous powder. Its molecular formula was determined as $\mathrm{C}_{13} \mathrm{H}_{11} \mathrm{NO}_{3}$ on the basis of HRESIMS at $\mathrm{m} / z 230.0819$ $[\mathrm{M}+\mathrm{H}]^{+}$(calcd. 230.0817 for $\mathrm{C}_{13} \mathrm{H}_{12} \mathrm{NO}_{3}$ ) and ${ }^{1} \mathrm{H}$ and ${ }^{13} \mathrm{C}$ NMR spectra data (Table 1). The IR spectrum of 1 showed strong $-\mathrm{CONH}_{2}$ bands at 3350 and $1680 \mathrm{~cm}^{-1}$, carbonyl band at $1759 \mathrm{~cm}^{-1}$, and phenyl bands at 1567,718 and $697 \mathrm{~cm}^{-1}$. ${ }^{1} \mathrm{H}$ NMR data of $\mathbf{1}$ showed two amide protons at $\delta 9.07$ (brs, 1H) and 5.94 (brs, 1H), five phenyl protons at $\delta 7.24(\mathrm{~d}, J=7.3 \mathrm{~Hz}, 2 \mathrm{H}), 7.37(\mathrm{t}, J=7.3 \mathrm{~Hz}, 2 \mathrm{H})$ and 7.32 $(\mathrm{t}, J=7.3 \mathrm{~Hz}, 1 \mathrm{H})$, two aromatic protons at $\delta 8.73(\mathrm{~s}, 1 \mathrm{H})$ and $6.25(\mathrm{~s}, 1 \mathrm{H})$, and two methylene protons at $\delta 3.89(\mathrm{~s}$, $2 \mathrm{H}) .{ }^{13} \mathrm{C}$ NMR and DEPT spectra data of 1 revealed two carbonyl carbons and two quaternary carbons at low field ( $\delta$ 162 178), seven $s p^{2}$ methine carbons, and a $s p^{3}$ methylene carbon $(\delta 39.6, \mathrm{t})$.

Three structural moieties of $\mathbf{1}$, including benzyl group (A), carbamino group (B) and 3,6-disubstituted $\gamma$-pyrone (C), were deduced by comprehensive interpretation of its ${ }^{1} \mathrm{H},{ }^{13} \mathrm{C}$, DEPT NMR, and ${ }^{1} \mathrm{H}-{ }^{1} \mathrm{H}$ COSY, HMQC and HMBC spectra (Fig. 2). The key long rang connections between H-2 $(\delta 8.73)$ with $\mathrm{C}-14(\delta 164.0, \mathrm{~s}), \mathrm{H}-5(\delta 6.25)$ with $\mathrm{C}-7(\delta 39.6, \mathrm{t})$, and $\mathrm{H}-7(\delta 3.89)$ with $\mathrm{C}-5(\delta 116.0, \mathrm{~d})$ and C-6 $(\delta 168.8, \mathrm{~s})$ indicated that benzyl and carbaminowere connected to C- 6 and $\mathrm{C}-3$ of $\gamma$-pyrone nucleus, respectively. Thus, structure of $\mathbf{1}$ was elucidated as 6benzyl-4-oxo-4H-pyran-3-carboxamide (Fig. 1).

Carbonarone B (2), obtained as a colorless needles, $\mathrm{mp}$ 
Table 1 NMR spectral data of carbonarones A (1) and B (2) (ppm in $\left.\mathrm{CDCl}_{3}\right)^{a}$

\begin{tabular}{|c|c|c|c|c|c|c|}
\hline \multirow{2}{*}{ Position } & \multicolumn{3}{|c|}{1} & \multicolumn{3}{|c|}{2} \\
\hline & $\delta_{\mathrm{H}}(\mathrm{J}$ in $\mathrm{Hz})$ & $\delta_{\mathrm{C}}(\mathrm{m})$ & $\mathrm{HMBC}^{b}(\mathrm{H} \rightarrow \mathrm{C})$ & $\delta_{\mathrm{H}}(\mathrm{J}$ in $\mathrm{Hz})$ & $\delta_{\mathrm{C}}(\mathrm{m})$ & $\mathrm{HMBC}^{b}(\mathrm{H} \rightarrow \mathrm{C})$ \\
\hline 1 & & & & 11.86 brs & & \\
\hline 2 & $8.73 \mathrm{~s}$ & $162.0 \mathrm{~d}$ & $3,4,6,14$ & & $165.5 \mathrm{~s}$ & \\
\hline 3 & & $119.3 \mathrm{~s}$ & & & $106.0 \mathrm{~s}$ & \\
\hline 4 & & $178.1 \mathrm{~s}$ & & & $175.9 \mathrm{~s}$ & \\
\hline 5 & $6.25 \mathrm{~s}$ & $116.0 \mathrm{~d}$ & $3,4,6,7$ & $5.80 \mathrm{~s}$ & $99.8 d$ & $3,4,6,7$ \\
\hline 6 & & $168.8 \mathrm{~s}$ & & & $157.4 \mathrm{~s}$ & \\
\hline 7 & $3.89 \mathrm{~s}(2 \mathrm{H})$ & $39.6 \mathrm{t}$ & $5,6,8,9,13$ & $3.88 \mathrm{~s}(2 \mathrm{H})$ & $40.0 \mathrm{t}$ & $5,6,8,9,13$ \\
\hline 8 & & $133.7 \mathrm{~s}$ & & & $134.5 \mathrm{~s}$ & \\
\hline 9 & $7.24 \mathrm{~d}(7.3)$ & $129.1 \mathrm{~d}$ & $7,10,11,13$ & $7.28 \mathrm{~d}(8.0)$ & $129.2 d$ & $7,11,13$ \\
\hline 10 & 7.37 t (7.3) & $129.1 \mathrm{~d}$ & $8,9,12$ & $7.35 \mathrm{t}(7.0,8.0)$ & $129.1 \mathrm{~d}$ & $8,9,12$ \\
\hline 11 & $7.32 \mathrm{t}(7.3)$ & $127.8 d$ & $9,10,13$ & $7.31 \mathrm{t}(7.0)$ & $127.8 \mathrm{~d}$ & 9,13 \\
\hline 12 & $7.37 \mathrm{t}(7.3)$ & $129.1 \mathrm{~d}$ & $8,10,13$ & $7.35 \mathrm{t}(7.0,8.0)$ & $129.1 \mathrm{~d}$ & $8,10,13$ \\
\hline 13 & $7.24 \mathrm{~d}(7.3)$ & $129.1 \mathrm{~d}$ & $7,9,11,12$ & $7.28 \mathrm{~d}(8.0)$ & $129.2 \mathrm{~d}$ & $7,9,11$ \\
\hline 14 & & $164.0 \mathrm{~s}$ & & $10.07 \mathrm{~s}$ & $194.0 \mathrm{~d}$ & 4 \\
\hline 14- $\mathrm{NH}_{2}$ & 9.07 br s, 5.94 brs & & & & & \\
\hline $4-\mathrm{OH}$ & & & & 13.67 br s & & $3,4,5$ \\
\hline
\end{tabular}

${ }^{a}{ }^{1} \mathrm{H},{ }^{13} \mathrm{C}$ NMR and $\mathrm{HMBC},{ }^{1} \mathrm{H}-{ }^{1} \mathrm{H}$ COSY spectra were obtained at $600 \mathrm{MHz}, 150 \mathrm{MHz}$ and $600 \mathrm{MHz}$, and recorded in $\mathrm{CDCl}_{3}$ at room temperature, respectively. Unless otherwise indicated, all proton signals integrated to $1 \mathrm{H}$.

${ }^{b}$ Carbon atoms coupled with proton. Multiplicity was determined by DEPT data.

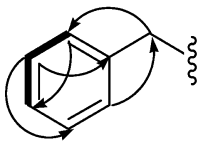

A<smiles>CC(N)=O</smiles>

B<smiles>Cc1oc2ccccc2c(=O)c1C(N)=O</smiles>

Fig. 2 Key COSY and HMBC correlations for 1.

$209 \sim 209.5^{\circ} \mathrm{C}$. The molecular formula of 2 was also determined as $\mathrm{C}_{13} \mathrm{H}_{11} \mathrm{NO}_{3}$ according to its ${ }^{1} \mathrm{H}$ and ${ }^{13} \mathrm{C}$ NMR spectra data (Table 1) and HRESIMS at $\mathrm{m} / \mathrm{z} 230.0824$ $[\mathrm{M}+\mathrm{H}]^{+}$(calcd. 230.0817 for $\mathrm{C}_{13} \mathrm{H}_{12} \mathrm{NO}_{3}$ ). The IR spectrum showed $-\mathrm{CHO}$ bands at $2826,2754 \mathrm{~cm}^{-1}$, carbonyl band at $1673 \mathrm{~cm}^{-1}$, and phenyl bands at 1560, 755 and $692 \mathrm{~cm}^{-1}$. The ${ }^{1} \mathrm{H}$ NMR data of $\mathbf{2}$ showed one hydroxyl proton at $\delta 13.67(\mathrm{br} \mathrm{s}, 1 \mathrm{H})$, one amide proton at $\delta 11.86$ (brs, 1H), one aldehyde proton at $\delta 10.07(\mathrm{~s}, 1 \mathrm{H})$, five phenyl protons at $\delta 7.28(\mathrm{~d}, J=8.0 \mathrm{~Hz}, 2 \mathrm{H}), 7.35$ (dd, "t" like, $J=7.0,8.0 \mathrm{~Hz}, 2 \mathrm{H})$ and $7.31(\mathrm{t}, J=7.0 \mathrm{~Hz}, 1 \mathrm{H})$, one

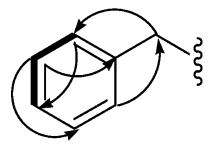

A<smiles>CC=O</smiles>

$\mathrm{B}$<smiles>O=C1NC(C23CC4CC(CC(C4)C2)C3)C2CCCC1C2</smiles>

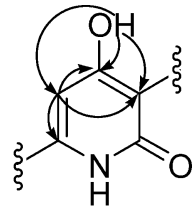

C
Fig. 3 Key COSY and HMBC correlations for 2.

vinyl proton at $\delta 5.80(\mathrm{~s}, 1 \mathrm{H})$, and two methylene protons at $\delta 3.88(\mathrm{~s}, 2 \mathrm{H}) .{ }^{13} \mathrm{C}$ NMR and DEPT spectra data of 2 revealed one aldehyde carbon $(\delta$ 194.0, d), one carbonyl carbon $(\delta 165.5, \mathrm{~s})$, six $s p^{2}$ methine carbons and four $s p^{2}$ quaternary carbons, and one $s p^{3}$ methylene carbon ( $\delta 40.0$, t) in the high field.

Detailed analysis of 1D and 2D NMR spectra data of 2 resulted in the elucidation of three structural moieties, i.e. benzyl group (A), aldehyde group (B) and 3,6disubstituted-4-hydroxy- $\alpha$-pyridone (C) (Fig. 3). The key HMBC correlations from H-5 $(\delta 5.80)$ to $\mathrm{C}-7(\delta 40.0, \mathrm{t})$, 


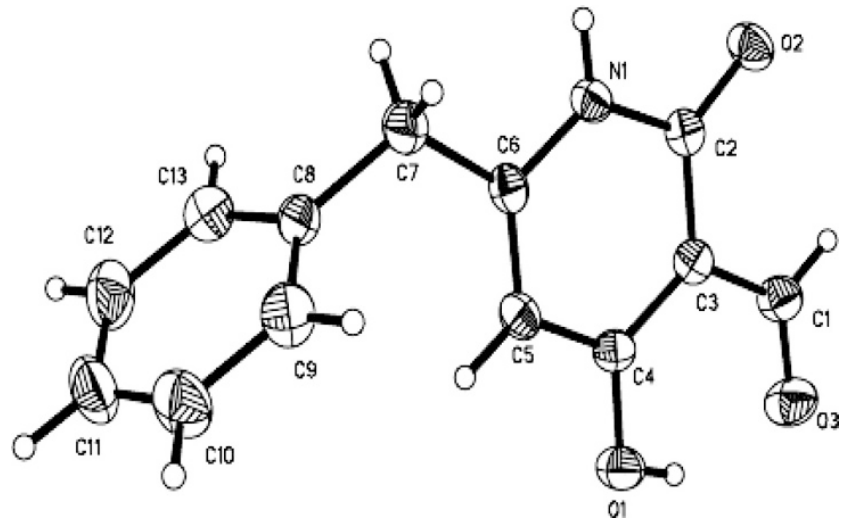

Fig. 4 X-Ray molecular structure of carbonarone B (2).

H-7 $(\delta 3.88)$ to both $\mathrm{C}-5(\delta 99.8, \mathrm{~d})$ and C-6 $(\delta 157.4, \mathrm{~s})$, and H-14 $(\delta 10.07)$ to both $\mathrm{C}-4(\delta 175.9, \mathrm{~s})$ and $\mathrm{C}-3(\delta$ $106.0, \mathrm{~s})$ clearly indicated that benzyl and aldehyde group was attached to C-6 and C-3 of $\alpha$-pyridone nucleus, respectively (Fig. 3), which was further confirmed by X-ray diffraction experiment (Fig. 4).* Thus, structure of 2 was unambiguously elucidated as 6-benzyl-4-hydroxy-2-oxo1,2-dihydropyridine-3-carbaldehyde.

To the best of our knowledge, compounds with benzyl group substituted $\alpha$-pyridone are extremely rare in nature, and compounds with benzyl group substituted $\gamma$-pyrone from natural resource have not been reported before.

\section{Cytotoxic Activities}

The cytotoxic effects of $\mathbf{1}$ and $\mathbf{2}$ were preliminarily evaluated in K562, P388, A-549, BEL-7402 and HL60 cell lines. Both compounds $\mathbf{1}$ and $\mathbf{2}$ exhibited moderate antiproliferative activity against $\mathrm{K} 562$ cell lines with $\mathrm{IC}_{50}$ value of 56.0 and $27.8 \mu \mathrm{g} / \mathrm{ml}$, respectively, while they were inactive against the other tested cell lines $\left(\mathrm{IC}_{50}>100 \mu \mathrm{g} / \mathrm{ml}\right)$.

\section{Experimental}

Melting points were measured using a Yanaco MP-500D micro-melting point apparatus and were uncorrected. Optical rotations were obtained on a JASCO P-1020 digital polarimeter. UV spectra were recorded on Beckman DU ${ }^{\circledR}$ 640 spectrophotometer. IR spectra were taken on a NICOLET NEXUS 470 spectrophotometer in $\mathrm{KBr}$ discs. ${ }^{1} \mathrm{H},{ }^{13} \mathrm{C}$ NMR and DEPT spectra and 2D-NMR were recorded on a JEOL Eclips-600 spectrometer using TMS as internal standard and chemical shifts were recorded as $\delta$ values. ESI-MS was measured on a Q-TOF ULTIMA GLOBAL GAA076 LC mass spectrometer. Semipreparative HPLC was performed on a SHIMADZU LC-6AD Liquid Chromatograph with SPD-M10A $v p$ Diode Array Detector.

Acknowledgement This work was financially supported by the Chinese National Programs for High Technology Research and Development (No. 2003AA624020), the Chinese National Natural Science Fund (No. 30670219), and the project of international cooperation of Australian and Chinese (2005 DFA 30030-4).

\section{References}

1) Wei H, Takuya I, Masahiro K, Yasuhide N, Mineko K, Motomasa K. Cytotoxic sesterterpenes, 6-epi-ophiobolin G and 6-epi-ophiobolin $\mathrm{N}$, from marine derived fungus Emericella variecolor GF10. Tetrahedron 60: 6015-6019 (2004)

2) John WB, Brent RC, Murray HGM, Peter TN, Michele RP. Marine natural products. Nat Prod Rep 22: 15-61 (2005)

3) Hatano $T$, Uebayashi $H$, Ito $H$, Shioto $S$, Tsuchia T, Yoshida T. Phenolic constituents of cassia seeds and antibacterial effect of some naphthalenes and anthraquinones on methicillin-resistant Staphylococcus aureus. Chem Pharm Bull 47: 1121-1127 (1999)

4) Graham JG, Zhang H, Pendland SL, Santarsiero BD, Mesecar AD, Cabieses F, Farnsworth NR. Antimycobacterial
* X-ray crystal structure analysis of compound 2: colorless needle crystal of $\mathrm{C}_{13} \mathrm{H}_{11} \mathrm{NO}_{3}$. Space group P-1, $a=4.774$ (5) $\AA$, $b=9.248$ (10) $\AA, c=13.332$ (14) $\AA, \alpha=95.889(14)^{\circ}, \beta=98.411$ $(15)^{\circ}, \gamma=102.340(15)^{\circ}, V=563.3$ (10) $\AA^{3}, Z=2$, crystal size $0.70 \times 0.43 \times 0.27 \mathrm{~mm}^{3}$. A total of 1933 unique reflections $\left(2 \theta<50^{\circ}\right)$ were collected using graphite monochromated Mo K $\alpha$ $(\lambda=0.71073 \AA)$ on a CCD area detector diffractometer. The structure was solved by direct methods (SHELXS-97) and expanded using Fourier techniques (SHELXS-97). The final cycle of full-matrix least squares refinement was based on 1933 unique reflections $\left(2 \theta<50^{\circ}\right)$ and 154 variable parameters and converged with unweighted and weighted agreement factors of $R=0.0992$, $R_{\mathrm{w}}=0.1670$ and $R_{1}=0.0622$ for $I>2.0 \sigma(I)$ data. Crystallographic data (excluding structure factors) for structure $\mathbf{2}$ in this paper have been deposited with the Cambridge Crystallographic Data Centre as supplementary publication number CCDC 615239. Copies of the data can be obtained, free of charge, on application to CCDC, 12 Union Road, Cambridge CB2 1EZ, UK [fax: +44 (0) 1223 336033 or e-mail: deposit@ccdc.cam.ac.uk]. 
Naphthopyrones from Senna obliqua. J Nat Prod 67: 225-227 (2004)

5. Joosten HMLJ, Goetz J, Pitte A, Schellenberg M, Bucheli P. Production of ochratoxin A by Aspergillus carbonarius on coffee cherries. Int J Food Microbiol 65: 39-44 (2001)

6. Bloomer JL, Caggiano TJ, Smith CA. Demonstration of an alternative chain folding in the pyranonapthalene fonsecin.
Tetrahedron Lett 23: 5103-5106 (1982)

7. Alfatafta AA, Dowd PF, Gloer JB, Wicklow DT. Carbonarin antiinsectan metabolites. U.S. 5,519,052, May 21, 1996

8. Skechan P, Storeng R, Scudiero D, Monks A, Mcmahon J, Vistica D, Warren JT, Bokesch H, Kenney S, Boyd MR. New colorimetric cytotoxicity assay for anticancer-drug screening. J Natl Cancer Inst 82: 1107-1112 (1990) 